\title{
Representation about Widow on Mass Media Content
}

\author{
Yuliyanto Budi Setiawan ${ }^{1}$, Prof. Dr. Billy K. Sarwono ${ }^{* 1}$, Dr. Donna Asteria ${ }^{1}$, Dr. Sunarto ${ }^{2}$ \\ ${ }^{1}$ Department of Communication, Universitas Indonesia; Jl. Salemba Raya 4, Jakarta. \\ ${ }^{2}$ Department of Communication, Universitas Diponegoro, Tembalang Semarang.
}

\begin{abstract}
This research looks at the media text side, and aims to describe the symbolic violence of widows displayed in mass media content, especially the content in Film Television (FTV). Starting from such a goal, this study uses semiotics (Roland Barthes) as a guide of thought as well as a technique of text analysis. This study also uses the concepts of representation as well as Pierre Bourdieu's idea of symbolic violence. The research object are FTV programs in Indonesia, including: FTV Indosiar, FTV MNC TV, FTV TRANSTV, FTV RCTI, FTV GlobalTV, SCTV FTV and FTV TRANS7 are selected purposively. The observation object are FTV programs that still display and represent the existence of symbolic violence toward widows. The results of this research found that television has not create equality and justice gender as yet, proven by the existence of the symbolic violence about widows on FTV show.
\end{abstract}

Keywords: Widow Representation, Text Media, Symbolic Violence, FTV Show

\section{Introduction}

Widow, one word which is translated in Kamus Besar Bahasa Indonesia (KBBI), means woman who have no longer husbands due to divorce or due to her husband death [1]. A widow, a word that should be the same status according to KBBI with widower status, but being a widow means will inevitably receive a 'stab' because the reality of the widow is much more painful than being a widower, in addition because of the myths are attached and also because of the various negative meanings that surround it, at least this has been felt by one of the widow who has initial name: HA.

HA said once upon a time when his friends suddenly keep a distance, or his best friend (male) since they were high school was worried when HA wanted to ride with his car on his way home after breaking fast together, his friend said, "Sorry I can't, I'm afraid my wife mad on me, you know, my wife is a person such of jealousy." In addition, HA once felt a time to lose self-esteem so drastically, because other people/stranger men easily invite her to 'sleep together', even though she has been wearing hijab. The symbolic violence of such a terrifying widow's status made her ever decided to ask her husband to be polygamous rather than divorce, but her effort failed (her husband keep divorced from her).

When the widow's status was finally forced for her, but for the sake of 'security' he never changed the status in the Kartu Keluarga (KK) and his Kartu Tanda Penduduk (KTP) even though the High Court of Religion has issued a decree. This condition lasted for many years, she chose to remain a 'wife' on paper (KK and KTP) with a man who is actually married again to another woman who is 10 years younger than her. HA stated that divorce will forever be a frightening specter for women. It's not just being physically separated or being alone again, but the discrimination such sexual harassment attached to a woman after she becomes a widow by painful words from another person.

The threat of violence as if did not want to be separated from women, proved when women was married, she was vulnerable to violence, then after becoming a widow, she also experienced violence as well. As previously stated that various forms of discrimination, symbolic violence to sexual harassment from the surrounding environment, are attached to women after their widow status, even if it is 'just' in the form of words.

Then, how if the phenomenon of violence toward the widows is associated with the mass media content, does the media content also represent discrimination by symbolic violence to sexual harassment for widows? To answer that question, a semiotics study (Roland Barthes) [2] is needed, in order to reveal the meaning behind the signs and symbols that appear in the contents of the mass media.

The mass media are actually required to take an objective position, especially when it comes to sensitive conflicts, such as religious conflicts, gender conflicts and conflicts between groups. But, on the reality, media precisely put forward and highlight the conflict. For the context of this study, the television media (Indosiar, MNC TV, TRANS TV, TRANS7, SCTV, RCTI and Global TV) through their FTV show, based on preliminary observations, show violent conflicts whose victims are female (widows) [3].

\footnotetext{
*Corresponding author: billysarwono@gmail.com
} 
Therefore, FTV can be regarded as a controversial show, so Komisi Penyiaran Indonesia (KPI) should make strict action related to television programs (especially FTV) that until now still use titles and also provocative contents, intended for women in general and widows in particular, in which woman/widow is only used as a sexual object/sex object only, that is not appropriate, such as: 'Mati Dipelukkan Janda', 'Janda Muda Berebut Satu Pria', 'Tiga Janda Gambreng', 'Derita Janda Kembang' and so forth. Moreover, from all existing communication media, television is still regarded as the most influential medium in human life. In addition, according to Nielsen data 2016, watching television/FTV is an activity that is still favored by children and adolescents, visible from the high ratings obtained by some FTV titles in the period April-June 2016, which up to now, the rating is still considered an excuse the main television show a program.

If violence against women/widows displayed in the FTV seems to be normalized/considered fair by the media, then watched by many person (ranging from children, adolescence to adulthood), then will be accepted by the audience/media audiences as something legitimate and normal too. Such a term of violence is what Pierre Bourdieu, referred to as symbolic violence. These factors also underlie why FTV show observed by researchers.

\section{Methodology}

This is a qualitative research, with primary and secondary data. This study uses semiotics (Roland Barthes) as a guide of thought as well as a technique of text analysis (primary data), while secondary data were collected through books, journal, and mass media.

\section{Discussion}

Based on Catatan Tahunan (CATAHU) of Komisi Nasional Anti Kekerasan terhadap Perempuan (Komnas Perempuan) from 2013 to 2017, it noted that the number of divorce cases handled by the Religious Courts tend to increase, although in 2017 tend to little decrease, but when viewed from the number of cases, is still relatively high. Below are the details of the case number, reaching 203.507 cases in 2013 [4]; 263.285 cases in 2014 [5]; 280.710 cases in 2015 [6], 305.535 cases in 2016 [7], and 245.548 cases in 2017 [8].

The number of divorce cases is a social reality that is worrying or arguably a terrible social reality, because women and/or children are always the victims of the divorce case. There are a number of reasons, such as: first, before the divorce, women/wives are vulnerable to violence by their husbands (whether physical, psychological, economic or sexual violence) which is the highest recorded (according to CATAHU (by Komnas Perempuan)) in the domestic realm. The following details of the percentage of Violence toward Wives (Kekerasan Terhadap Istri (KTI)) compared to the total number of cases of Domestic Violence (Kekerasan dalam Rumah Tangga (KdRT)) that occurred in the last five years in Indonesia, including: $66 \%$ KdRT derived from KTI (CATAHU 2013), 64\% KdRT of KTI (CATAHU 2014), 59\% of KdRT are from KTI (CATAHU 2015), 60\% of KdRT are from KTI (CATAHU 2016) and $56 \%$ of KdRT are from KTI (CATAHU 2017).

In this study, researchers reviewed the two contents of FTV, including: 'Mati Dipelukan Janda' and 'Tiga Janda Gambreng.' Then, based on semiotical analysis Roland Barthes, the two FTV shows represent discrimination, symbolic violence to sexual abuse of widows. The widow is represented always rely on man, undergoing a limited profession, always afraid about herself, as a sexual object, always blamed and passive, and performs the function of consuming goods or services. In addition, through Barthes's frame of mind, researchers can reveal the dominant values (patriarchy) that apply in the shows. Meanwhile, media representations themselves reflect certain views of social groups. These views are what human beings/audiences are unconsciously, and accept them as normal and put aside alternative views.

If violence against women/widows displayed in the FTV seems to be normalized/considered fair by the media, then watched by many person (ranging from children, adolescence to adulthood), then will be accepted by the audience/media audiences as something legitimate and normal too. Such a term of violence is what Pierre Bourdieu [9], referred to as symbolic violence. These factors also underlie why FTV show observed by researchers.

There are many things need to be criticized on the content in the media about widows representation that should not be displayed like that! The media should be the spearhead in educating community to make equal meaning of widow and widower.' Unfortunately, until now FTV shows still presenting negative image of widows and the positive image of widower in the minds of the audience.

\section{Conclusion}

Not surprisingly when we heard the word 'janda', then in our memory flare additional words like 'kembang' or 'muda' or 'genit' which will accompany the word 'janda', so eventually the terms become: 'janda kembang,' 'janda muda, 'janda genit', janda gambreng, janda bodong and so forth. Then, why in our memory have negative feeling with the terms of widow? Does the media have a 'contribution' in perpetuating those terms?

Based on Roland Barthes's semiotic analysis results, mass media participate in instilling and preserving collective memory passed down from generation to generation so that it can become a culture, related to negative portrayal about widow as minority [10]. Take a look at so many Film Television titles (FTV) and content about the widow identified with 'flirty', 'marital destruction' and various other stigmas. Yet in reality, not all widows have a negative character, even if there is a 
character like that, can be said as a certain person, but unfortunately people consider all such widows. Therefore, it can be said that the mass media (television in particular) has not create equality and justice gender as yet, proved by existence of symbolic violence toward widows on FTV show.

Seeing that women with the term of widow displayed on FTV is heavily disregarded and full of negative nuance, thus further research should see how FTV perspective displays rural people merely attached with village, rice field, and isolated environment. It is able to lead public to characterize rural areas solely about natural environment and justify environment to be exploited.

\section{References}

1. Kamus Besar Bahasa Indonesia (KBBI), "Kamus versi Online/Daring (dalam Jaringan)”, Accessed October 13 (2017).

2. R. Barthes, "Mythologies", The Noonday Press, New York (1991).

3. E. D. S Watie, "Representasi Wanita Dalam Media Massa Masa Kini”, Jurnal The Messenger, 2(2), 1-10 (2016).
4. Komnas Perempuan, "Catatan Kekerasan terhadap Perempuan Tahun 2013: Kegentingan Kekerasan Seksual, Lemahnya Upaya Penanganan Negara", Komnas Perempuan, Jakarta (2014).

5. Komnas Perempuan, "Catatan Kekerasan terhadap Perempuan Tahun 2014: Negara segera Putus Impunitas Pelaku”, Komnas Perempuan, Jakarta (2015).

6. Komnas Perempuan, "Catatan Kekerasan terhadap Perempuan Tahun 2015: Kekerasan terhadap Perempuan Meluas: Negara Urgen Hadir Hentikan Kekerasan terhadap Perempuan di Ranah Domestik, Komunitas dan Negara”, Komnas Perempuan, Jakarta (2016).

7. Komnas Perempuan, "Catatan Kekerasan terhadap Perempuan Tahun 2016", Komnas Perempuan, Jakarta (2017).

8. Y. Widodo, "Kuasa Rating dan Tayangan Tak Bermutu”, REMOTIVI, Pusat Kajian Media dan Komunikasi, Accessed August 12 (2017).

9. R. Jenkins, "Membaca Pikiran Pierre Bourdieu (Edisi Revisi)”, Kreasi Wacana, Bantul (2016).

10. N. Marmaryan, "Minority Concept and Related Issues”, 63-68 (2010). 